\title{
THE EFFECT OF MG AND S ON PHOTOSYNTHESIS PRODUCTS AND NITROGEN CONTENT IN WINTER WHEAT
}

Rūta DROMANTIENE், Institute of Agroecosystems and Soil Science, Faculty of Agronomy, Aleksandras Stulginskis University. Studentų g. 11, Akademija LT-53361, Kauno r, Lithuania. ruta.dromantietiene@asu.lt (coresponding author)

Irena PRANCKIETIENE், Institute of Agroecosystems and Soil Science, Faculty of Agronomy, Aleksandras Stulginskis University. Studentu g. 11, Akademija LT-53361, Kauno r, Lithuania. irena.pranckietiene@asu.lt

Gvidas SIDLAUSKAS, Institute of Agroecosystems and Soil Science, Faculty of Agronomy, Aleksandras Stulginskis University. Studentu g. 11, Akademija LT-53361, Kauno r, Lithuania. sgvidas@ gmail.com.

Vita SMALSTIENE், Institute of Agroecosystems and Soil Science, Faculty of Agronomy, Aleksandras Stulginskis University. Studentu g. 11, Akademija LT-53361, Kauno r, Lithuania. vita.smalstiene@asu.lt

In 2013 and 2014, field experiments involving winter wheat were conducted at Aleksandras Stulginskis University's Experimental Station on a medium-textured Cal(ca)ri-Epihypogleyic Luvisol. $\mathrm{N}_{150} \mathrm{P}_{90} \mathrm{~K}_{120}$ were applied as the main fertilizers. Additionally, a foliar fertilizer including amide nitrogen, sulphur and magnesium ( $\mathrm{MgO}$ concentrations ranging from $0.25 \%$ to $2.5 \%$ ), (further referred to as magnesium fertilizer), was sprayed at the tillering and booting stages of winter wheat.

It was found that magnesium fertilizer foliar-applied at the end of tillering and booting stages tended to increase chlorophyll $a$ and $b$ contents in winter wheat leaves. Chlorophyll $a$ content in leaves significantly increased when the solution with $2.5 \%$ concentration of magnesium had been applied at tillering and when $0.5,1.0$ and $2.5 \%$ concentrations of the solution had been applied at booting stages. Chlorophyll $b$ content in winter wheat leaves was significantly affected by the solutions with $0.5,1.0$ and $2.5 \%$ magnesium concentrations at tillering and by the solutions with $0.5,1.0,1.5,2.0$ and $2.5 \%$ magnesium concentrations at booting stages. The highest increase in dry matter content was recorded when $2.5 \% \mathrm{MgO}$ solution had been applied at booting stage.

A statistically significant correlation was established between the $\mathrm{MgO}$ concentrations applied at tillering $\left(\mathrm{r}=0.905^{*}\right)$ and booting $(\mathrm{r}=$ $0.863^{*}$ ) stages and nitrogen content in winter wheat dry matter.

Keywords: nitrogen, magnesium, sulphur, chlorophyll

\section{INTRODUCTION}

Photosynthesis is the main physiological process which allow us to judge the plants' response to the environmental conditions and the efficiency of crop and soil management practices employed (Bojović and Stojanović, 2005; Bojovič, Markivič, 2009).

Magnesium is a constituent of chlorophyll which is involved in the processes of photosynthesis and starch synthesis. It is essential for phosphorus and sugar transfer to other parts of plants (Bergman, 1986; Carmak, Kirkby, 2008). Magnesium is indispensable for the activity of many enzymes (Cakmak and Kirkby 2008). The availability of Mg to plants depends on various factors: the distribution and chemical properties of the source rock material, soil properties, including $\mathrm{pH}$, concentration of other ions, moisture, temperature, site-specific climatic and anthropogenic factors, cultivated crop species and crop rotation, cropping intensity, organic and mineral fertilization practice (Mikkelsen 2010; Gransee and Führs 2013). Jaskulska et al. (2015) have found that magnesium content was at-the-highest-level linearly positively correlated with a soil $\mathrm{pH}$ and its richness.

Magnesium (Mg) is a very important element for soil properties and plant growth (Gransee and Führs, 2013). A sufficient amount of magnesium is necessary for winter crops during the autumn period, as it ensures the accumulation of sugars and other carbohydrates, which in turn facilitates overwinter survival (Gransee and Führs 2013). Magnesium deficiency in plants was found to firstly affect root development, which becomes evident already after 3 days (Cakmak and Kirkby, 2008). It has been documented that the disturbances in the development of the above-ground plant part manifest themselves after 10 days and visual symptoms of magnesium deficiency show up after 15 days (Hermans et al., 2004; Cakmak and Kirkby, 2008). In cereals, the amount of magnesium markedly decreases at the beginning of booting stage and this decrease depends little on the magnesium content in the soil.

Sulphur $(\mathrm{S})$ is one of the essential nutrients for crop growth, which is linked to nitrogen $(\mathrm{N})$ in many physiological functions (Salvagiotti and Miralles 2007). Without adequate sulphur, crops cannot reach their full potential in terms of yield. Sulphur deficiency significantly affects the production and quality of winter wheat (Järvan et al., 2012). Since udic

Copyright (C) 2017 The Authors. Published by Aleksandras Stulginskis University. This is an open-access article distributed under the terms of the Creative Commons Attribution License (CC-BY 4.0), which permits unrestricted use, distribution, and reproduction in any medium, provided the original author and source are credited. 
soil moisture regime predominates in Lithuania, sulphur balance is negative in the soil (Gužys and Aksomaitienè, 2005). Balanced sulphur fertilization ensures abundant and high-quality yield (McGrath et al., 2002; Erdem et al., 2016).

The current study was aimed to identify the most suitable magnesium fertilizer rates and to assess the efficiency of this element for winter wheat.

\section{MATERIALS AND METHODS}

Field experiments involving a winter wheat variety 'Ada' were set up at Aleksandras Stulginskis University's Experimental Station in 2013 and 2014. The experimental plots were laid out in a randomized block design with four replications on a medium-textured Cal(ca)ri-Epihypogleyic Luvisol with a $\mathrm{pH}_{\mathrm{KCl}}$ of 7.2, phosphorus $\left(\mathrm{P}_{2} \mathrm{O}_{5}\right)$ content of $264 \mathrm{mg} \mathrm{kg}^{-1}$, potassium $\left(\mathrm{K}_{2} \mathrm{O}\right)$ content of $162 \mathrm{mg} \mathrm{kg}^{-1}$ and organic carbon content of $1.21 \%$.

Background fertilization of winter wheat: granulated superphosphate $\left(\mathrm{P}_{90}\right)$ and potassium chloride $\left(\mathrm{K}_{120}\right)$ were applied in the autumn, before sowing; ammonium nitrate $\left(\mathrm{N}_{150}\right)$ was applied in the spring after resumption of the vegetative growth (BBCH 22-24). The magnesium fertilizer was foliar-applied at the end of tillering stage (BBCH 27-29) and at booting stage (BBCH 32-35). The following concentrations of $\mathrm{MgO}$ were used: $0.25 \%, 0.5 \%, 0.75 \%, 1.0 \%$, and $2.5 \%$. The composition of the liquid amide nitrogen fertilizer was as follows: $\mathrm{N}^{-\mathrm{NH}_{2}} 15 \%, \mathrm{MgO} 7 \%, \mathrm{SO}_{3} 14 \%$. The total volume of the solution was $2001 \mathrm{ha}^{-1}$. The rates of fertilizer were calculated according to the $\mathrm{MgO}$ content in it.

Experimental and analytical methods. The soil was analysed for $\mathrm{pH}_{\mathrm{KCl}}$ measured in $1 \mathrm{~N} \mathrm{KCl} \mathrm{extraction} \mathrm{by} \mathrm{a} \mathrm{potentiometric}$ method, organic carbon $(C)$ by the Tyurin method, available phosphorus $\left(\mathrm{P}_{2} \mathrm{O}_{5}\right)$ and available potassium $\left(\mathrm{K}_{2} \mathrm{O}\right)$ by the Egner-Riehm-Domingo (A-L) method, mineral nitrogen $\left(\mathrm{N}_{\min }\right)$ by $1 \mathrm{~N} \mathrm{KCl} \mathrm{extraction,} \mathrm{the} \mathrm{total} \mathrm{nitrogen} \mathrm{by} \mathrm{the} \mathrm{Kjeldahl}$ method. Ten days after additional fertilization, plant samples (10 per plot) were analysed for the chlorophyll $a$ and $b$ concentrations in leaves (according to after D. Wettstein), the content of dry matter was determined by drying the samples to a constant weight at a temperature of $105^{\circ} \mathrm{C}$ (LST ISO 751:2000). Nitrogen content (\%) in plants was measured by the Kjeldahl method (LST ISO 20483). All experimental data were statistically processed by the analysis of variance (ANOVA) using a software package SELEKCIJA (Tarakanovas and Raudonius 2003). The correlation coefficients and relationships between the indicators tested were determined using the software STATISTICA 7 (Hill and Levicki, 2005).

\section{RESULTS AND DISCUSSION}

In the field experiments, magnesium and sulphur were found to increase the content of chlorophyll $a$ in winter wheat leaves. Ten days after application of liquid magnesium fertilizer at tillering stage, the leaves were found to have $0.08-0.25 \mathrm{mg} \mathrm{g}^{-1}$ more chlorophyll $a$, compared with the control treatment (Fig. 1). Significantly the highest chlorophyll $a$ content $\left(2.10 \mathrm{mg} \mathrm{g}^{-1}\right)$ was recorded in the treatment fertilized at the tillering stage with a $2.5 \%$ concentration of the fertilizer solution.

The correlation-regression analysis indicated that in the treatments fertilized at the tillering stage, chlorophyll $a$ content in leaves ten days after application varied depending on the concentration of the fertilizer solution according to the linear equation (Fig. 3). The relationship between these indicators was very strong $\left(r=0.908^{*}\right)$. The published data suggest that chlorophyll content is closely related to physiological activity of plants and accumulation of assimilates. Marschner (2011) suggests that the share of the total Mg bound to chlorophyll depends on the $\mathrm{Mg}$ status and ranges from about 6 to $25 \%$. Laing et al. (2000) have established that plants containing low concentrations of magnesium contain lower chlorophyll content.

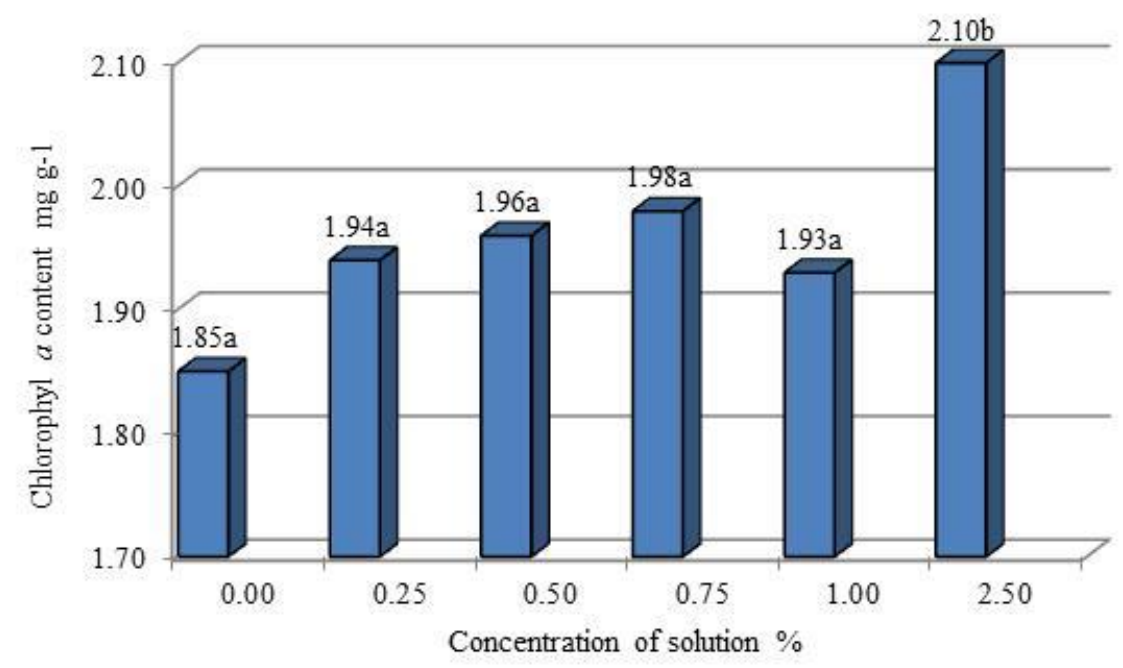

Note - values followed different letters are statistically significant $(P<0.05)$

Figure 1. The content of chlorophyll $a$ in winter wheat leaves 10 days after liquid magnesium fertilizer application at the tillering stage 
A higher efficacy of the magnesium fertilizer for the content of chlorophyll $a$ was identified in the treatments applied with foliar-fertilizer at the booting stage (when the second node had formed). The $0.5,1.0$ and $2.5 \%$ concentrations of the fertilizer significantly increased chlorophyll $a$ content in the leaves of winter wheat (Figure 2). Although the highest chlorophyll $a$ content 10 days after magnesium fertilizer application was determined in the leaves of wheat plants applied with $0.5 \%$ concentration of the solution, the plants applied with 1.0-2.5\% concentrations of the solution had only negligibly lower chlorophyll $a$ content in leaves, compared with the highest content. The application of magnesium fertilizer at $0.25 \%$ concentration of the solution did not justify itself, as chlorophyll $a$ content was only insignificantly $0.08 \mathrm{mg} \mathrm{g}^{-1}$ higher than in the control treatment. The correlation-regression analysis revealed a moderate $(\mathrm{r}=0.566)$ relationship between the chlorophyll $a$ content and the concentrations of the tested fertilizer (Figure 3). Magnesium also acts as a catalyst in many oxidation, reduction reactions inside the plant tissues, moreover magnesium is responsible for chlorophyll formation in the plant (Thalooth et al., 2006).

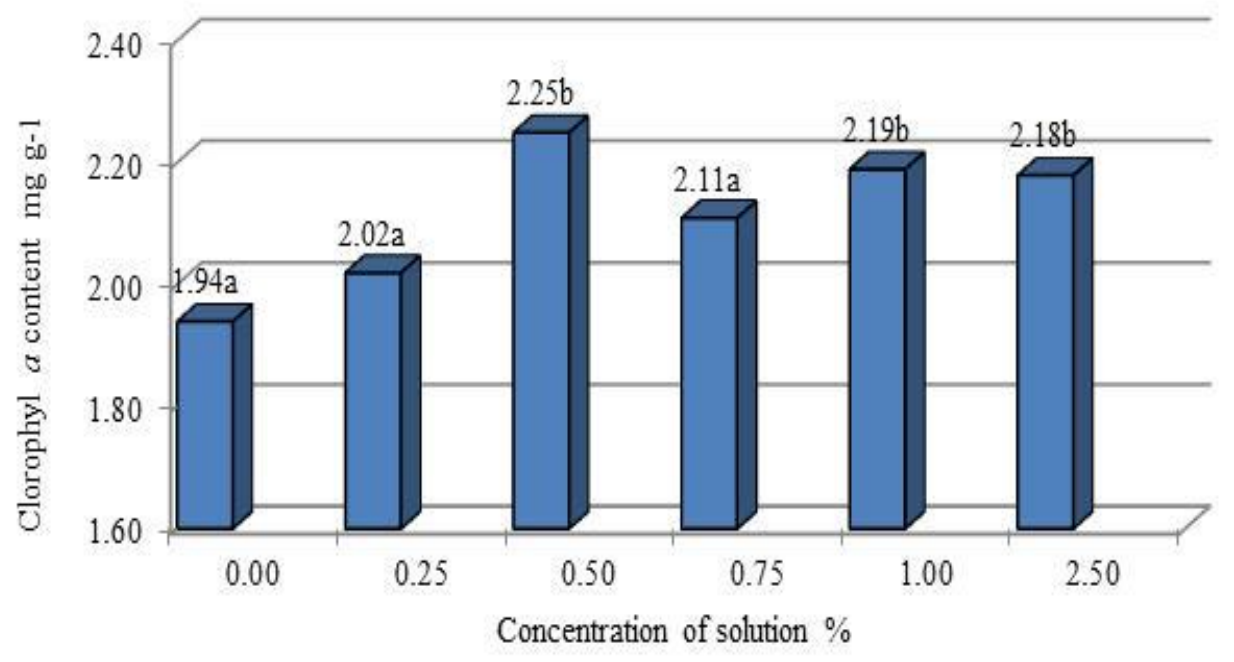

Note - values followed different letters are statistically significant $(P<0.05)$

Figure 2. The content of chlorophyll $a$ in winter wheat leaves 10 days after liquid magnesium fertilizer application at the booting stage

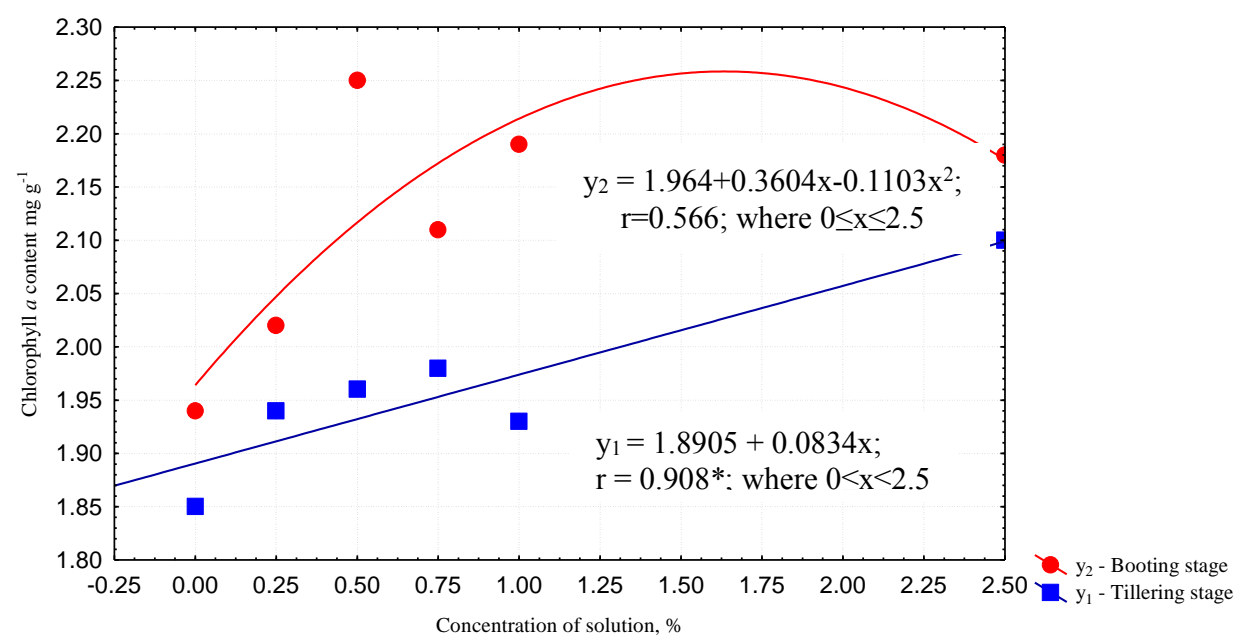

Note $*$ - statistically significant $\mathrm{P}<0.05$

Figure 3. The relationship between chlorophyll $a$ content $\left(\mathrm{y}, \mathrm{mg} \mathrm{g}^{-1}\right)$ in leaves and concentrations of solution $(\mathrm{x}, \%)$

The trends of variation of the content of the photosynthetic pigment, chlorophyll $b$, in winter wheat leaves as influenced by fertilization with magnesium fertilizer at tillering and booting stages are presented in Table 1. The solution of the lowest concentration $(0.25 \%)$ did not have significant effect on the variation of chlorophyll $b$. The solutions of $0.50-2.50 \%$ concentrations applied at the tillering stage markedly increased chlorophyll $b$ content in plants. Significantly higher chlorophyll $b$ content in winter wheat leaves was identified in the treatments fertilized with $2.5 \%$ concentration of the solution compared with all other treatments at tillering stage. 
Table 1. The content of chlorophyll $b$ in winter wheat leaves 10 days after magnesium fertilizer application at tillering and at booting stages

\begin{tabular}{|l|c|c|}
\hline \multicolumn{1}{|c|}{ Concentration of solution } & \multicolumn{2}{|c|}{ Chlorophyll $b$ content, $\mathrm{mg} \mathrm{g}^{-1}$} \\
\cline { 2 - 3 } & \multicolumn{2}{|c|}{ Tillering stage } \\
\hline Control & $0.51 \mathrm{a}$ & $0.45 \mathrm{a}$ \\
\hline $0.25 \% \mathrm{MgO}$ & $0.52 \mathrm{a}$ & $0.47 \mathrm{a}$ \\
\hline $0.50 \% \mathrm{MgO}$ & $0.58 \mathrm{~b}$ & $0.53 \mathrm{~b}$ \\
\hline $0.75 \% \mathrm{MgO}$ & $0.56 \mathrm{~b}$ & $0.60 \mathrm{~b}$ \\
\hline $1.00 \% \mathrm{MgO}$ & $0.56 \mathrm{~b}$ & $0.57 \mathrm{~b}$ \\
\hline $2.50 \% \mathrm{MgO}$ & $0.61 \mathrm{c}$ & $0.57 \mathrm{~b}$ \\
\hline
\end{tabular}

Note - values followed different letters are statistically significant $(P<0.05)$

A marked increase in chlorophyll $b$ content in leaves at booting stages was established ten days after application of $0.50-2.50 \%$ concentrations of the solution. The highest chlorophyll $b$ content in winter wheat leaves was established in the treatments applied with $0.75 \%$ concentration of the solution and only negligible lower content in the treatments applied with 1.0 and $2.50 \%$ concentrations of the solution.

Winter wheat fertilized with 0.25 and $0.5 \%$ concentrations of the solution at tillering stage accumulated not significantly higher content of dry matter in leaves compared with the control treatment (Table 2). With increasing concentrations of the solution, dry matter content in plants tended to decrease, compared with the control.

Winter wheat applied with foliar-fertilizer with the solutions of different concentrations of magnesium fertilizer at the beginning of booting stage had higher dry matter content 10 days after application (Table 2). Significantly the highest (1.88 percentage points) dry matter content was recorded in the wheat applied with $2.5 \%$ concentration of the solution at this stage comparing with control.

Table 2. The dry matter content 10 days after fertilization with liquid magnesium fertilizer at tillering and at booting stage

\begin{tabular}{|l|c|c|}
\hline \multirow{2}{*}{ Concentration of solution } & \multicolumn{2}{|c|}{ Dry matter, \% } \\
\cline { 2 - 3 } & Tillering stage & Booting stage \\
\hline Control & $16.20 \mathrm{a}$ & $18.43 \mathrm{a}$ \\
\hline $0.25 \% \mathrm{MgO}$ & $16.49 \mathrm{a}$ & $18.69 \mathrm{a}$ \\
\hline $0.50 \% \mathrm{MgO}$ & $16.50 \mathrm{a}$ & $18.51 \mathrm{a}$ \\
\hline $0.75 \% \mathrm{MgO}$ & $16.14 \mathrm{a}$ & $18.59 \mathrm{a}$ \\
\hline $1.00 \% \mathrm{MgO}$ & $16.13 \mathrm{a}$ & $19.03 \mathrm{a}$ \\
\hline $2.50 \% \mathrm{MgO}$ & $16.13 \mathrm{a}$ & $20.31 \mathrm{~b}$ \\
\hline
\end{tabular}

Note - values followed different letters are statistically significant $(P<0.05)$

Liquid magnesium fertilizer applied at both stages, end of tillering and beginning of booting, increased nitrogen uptake. Chemical analysis of the above-ground part of plants indicated that with increasing concentration of fertilizer the content of nitrogen increased in plants. The correlation-regression analysis showed a very strong relationship between these indicators at tillering stage and strong relationship - at booting stage, which was described by linear equations (Fig. 4).

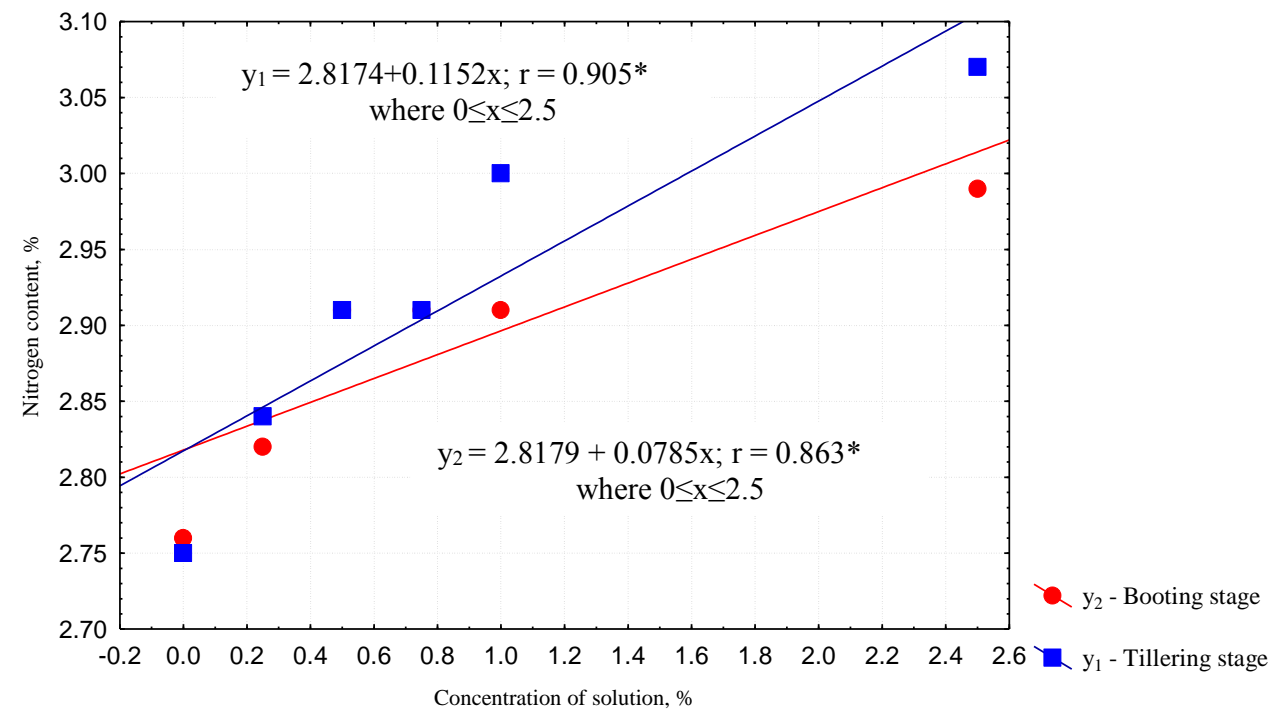

Note $*$ - statistically significant $\mathrm{P}<0.05$

Figure 4 . The relationship between nitrogen content $(\mathrm{y}, \%)$ in plant and concentrations of solution $(\mathrm{x}, \%)$

In other studies, magnesium content was found to correlate with nitrogen content in winter wheat leaves, the plants that had higher nitrogen content tended to have higher magnesium content, but lower potassium content (Jaskulska et al., 


\section{Proceedings of the $8^{\text {th }}$ International Scientific Conference Rural Development 2017}

2015). Grzebisz (2013) has shown that plant magnesium nutritional status is critical for both assimilate production in leaves and in the subsequent step, transportation to the growing ear. He suggests that any shortage of magnesium in plant may fate formation of yield structural elements.

\section{CONCLUSIONS}

The liquid magnesium fertilizer tested in the current study exerted positive effect on the photosynthetic processes in plants. This effect depended on the concentrations of the magnesium fertilizer solutions and plant growth stage at application. Chlorophyll $a$ content in leaves ten days after application had a tendency increased with increasing concentration of the fertilizer solution. Chlorophyll $b$ content in leaves varied inconsistently when winter wheat had been fertilized with the solutions containing different concentrations of $\mathrm{MgO}$ at the end of tillering stage. The most active synthesis of chlorophyll $b$ in the winter wheat leaves occurred in the treatments fertilized with $0.75,1.0$ and $2.5 \%$ concentrations of the solution at the booting stage.

A significant increase in dry matter content in wheat plants was recorded only in the treatments fertilized with $2.5 \%$ concentration of the solution at the booting stage. The chemical analysis of the above-ground part of plants indicated that with increasing fertilizer concentration, the content of nitrogen in plants increased.

\section{REFERENCES}

1. Bergmann, W. 1986. Ernährungsstörungen bei Kulturpflanzen. Entstehung, visuelle und analytische Diagnose. Jena: VEB Gustav Verlag, pp. 97-202.

2. Bojović, B., Markivić, A. 2009. Correlation between nitrogen and chlorophyll content in wheat (Triticum aestivum L.). Kragujevac Journal of Science, Vol. 31, pp. 69-74.

3.Bojović, B., Stojanović, J. 2005. Chlorophyll and carotenoid content in wheat cultivars as a function of mineral nutrition. Archives of Biological Sciences. Vo. 57, Iss. 4, pp. 283-290. https://doi.org/10.2298/ABS0504283B

4. Cakmak, I, Kirkby, E. A. 2008. Role of magnesium in carbon partitioning and alleviating photooxidative damage. Physiologia Plantarum. Vol. 133, Iss. 4, pp. 692-704 https://doi.org/10.1111/j.1399-3054.2007.01042.x

5. Erdem, H., Torun, M. B., Erdem, N., Yazıcı, A., Tolay, I., Gunal, E., Özkutlu, F. 2016. Effects of Different Forms and Doses of Sulphur Application on Wheat. Turkish Journal of Agriculture - Food Science and Technology. Vol. 4, Iss. 11, pp. 957-961. https://doi.org/10.24925/turjaf.v4i11.957-961.837

6. Gransee, A., Führs, H. (2013): Magnesium mobility in soils as challenge for soil and plant analysis, magnesium fertilization and root uptake under adverse growth conditions. Plant and Soil 368: 5-21. https://doi.org/10.1007/s11104-012-1567-y

7. Grzebisz, W. 2013. Crop response to magnesium fertilization as affected by nitrogen supply. Plant Soil. Vol. 368, pp. 23-39. https://doi.org/10.1007/s11104-012-1574-Z

8. Gužys, S., Aksomaitiene, R. 2005. Migration of sulphur in limed soils differing in agricultural management. Nutrient Cycling in Agroecosystems. Vol. 71, pp. 191-201. https://doi.org/10.1007/s10705-004-3175-6

9. Hermans, C., Johnson, G. N., Strasser, R. J., Verbruggen, N. 2004. Physiological characterization of magnesium deficiency in sugar beet: acclimation to low magnesium differentially affects photosystems I and II. Planta. Vol. 220, Iss. 2, pp. 344-355. https://doi.org/10.1007/s00425-004-1340-4

10. Hill, T., Levicki, P. 2005. Statistics methods and applications. Madison, USA, $800 \mathrm{p}$

11. Järvan, M., Edesi, L., Adamson, A. 2012.Effect of sulphur fertilization on grain yield and yield components of winter wheat. Soil and Plant Science. Vol 62, pp. 401-409.

12. Jaskulska, I., Jaskulski, D., Piekarczyk, M., Kotwica, K., Gałęzewski, L., Wasilewski, P. 2015. Magnesium content in the leaves of winter wheatin a long-term fertilization experiment. Plant, Soil and Environment. Vol. 61, 2015, No. 5: 208-212. doi: https://doi.org/10.17221/60/2015-PSE

13. Laing, W., Greer, D., Sun, O., Beets, P., Lowe, A., Payn, T. 2000. Physiological impacts of Mg deficiency in Pinus radiata: Growth and photosynthesis. New Phytologis., Vol. 146, Iss. 1, pp. 47-57. https://doi.org/10.1046/j.1469-8137.2000.00616.x

14. Marschner P. 2011. Marschner's Mineral Nutrition of Higher Plants. 3rd edition. Edited by Marschner P. Amsterdam, Netherlands: Elsevier/Academic Press, p. 684.

15. McGrath, S.P., Zhao, F.J., Blake-Kalff, M.M. 2002. History and outlook for sulphur fertilisers in Europe. Proc. No. 497, International Fertiliser Society, York, U.K.

16. Mikkelsen, R. 2010. Soil and fertilizer magnesium. Better Crops. 94:26-28.

17. Salvagiotti, F., Miralles, D. J. 2007. Wheat development as affected by nitrogen and sulfur nutrition. Australian Journal of Agricultural Research. Vol. 58, pp. 39-45. https://doi.org/10.1071/AR06090

18. Tarakanovas, P., Raudonius, S. 2003. Agronominių tyrimų duomenų statistinė analizè taikant kompiuterines programas ANOVA STAT. In: Programu paketas ,Selekcija“. Akademija, 60 p. [In Lithuanian]

19. Thalooth, A. T., Tawfik, M.,M., Magda Mohamed, H. 2006. A Comparative Study on the Effect of Foliar Application of Zinc, Potassium and Magnesium on Growth, Yield and Some Chemical Constituents of Mungbean Plants Grown under Water Stress Conditions. World Journal of Agricultural. Vol. 2, Iss. 1, pp. 37-46. 